\title{
Assessment of the competitiveness of domestic and foreign combine harvesters
}

\author{
Evgeny I. Vinevsky*, Vladimir K. Papusha, and Nikolay A. Nikitenko
}

Federal State Budgetary Educational Institution of Higher Education «Kuban State Agrarian University named after I.T. Trubilin» Krasnodar, Russia

\begin{abstract}
The assessment of the competitiveness of domestic and foreign designs of grain harvesters of various productivity in accordance with the calculation method proposed by GOST R 53057 - 2008 "Agricultural machines. Methods for assessing competitiveness". It is established that combine harvesters of LLC CP "Rostselmash" are more competitive in comparison with foreign designs mainly due to lower prices at comparable direct costs and labor productivity.
\end{abstract}

Currently, in the Russian Federation, grain harvesters of both domestic [1] and foreign manufacturers [2 -6] of various productivity are used for harvesting grain crops.

One of the areas of classification of grain harvesting equipment is the throughput capacity of its threshing and separating device (table 1).

Table 1. Classification of combine harvesters of the throughput capacity of the threshing and separating device

\begin{tabular}{|c|c|}
\hline Class & Throughput capacity, $\mathrm{kg} / \mathrm{s}$ \\
\hline I & $1-3$ \\
\hline II & $3-5$ \\
\hline III & $5-7$ \\
\hline IV & $7-9$ \\
\hline V & $9-11$ \\
\hline VI & $11-13$ \\
\hline VII & $13-15$ \\
\hline
\end{tabular}

Various methods have been developed to determine the most effective equipment for harvesting grain crops, allowing to establish promising combine harvesters based on a generalized parameter of a comprehensive assessment that takes into account operating costs, labor costs, energy and metal consumption, as well as capital investment and their payback period [7-9].

In 2008, the Russian Federation standard "GOST R 53057 - 2008 "Agricultural machinery came into force. METHODS FOR ASSESSING COMPETITIVENESS" [10]. According to the standard, the integral parameter of competitiveness for agricultural

* Corresponding author: vinevski@ mail.ru 
machinery from 1.0 to 1.1 indicates a low level of competitiveness, from 1.1 to 1.3 - an average level of competitiveness, from 1.3 and higher - a high level of competitiveness.

The purpose of the analysis of technological schemes and designs of combine harvesters of various manufacturers was to determine the most effective designs of combine harvesters for different values of throughput capacity of the threshing and separating device.

As criterion of an estimation of competitiveness adopted, an integral parameter that takes into account the following factors: factor price ratio of the competing machines $\mathrm{k}_{1}$; factor ratio of direct costs of the competing machines $\mathrm{k}_{2}$; factor ratio of labor productivity of the competing machines $\mathrm{k}_{3}$. The values of specific weight of factor coefficients of significance took the form $\gamma_{1}=\gamma_{2}=\gamma_{3}=0,33$ Table 2 .

Integral parameter of the harvester's competitiveness $\mathrm{k}_{\mathrm{M}}$, calculated by the equation

$$
\mathrm{k}_{\mathrm{M}}=\mathrm{k}_{1} \gamma_{1}+\mathrm{k}_{2} \gamma_{2}+\mathrm{k}_{3} \gamma_{3}
$$

Factor coefficient $\mathrm{k}_{1}$ of the price of a competing combine harvester was calculated using the formula

$$
k_{1}=\frac{Б_{\sigma}}{B_{\kappa}}
$$

where $\overline{5}_{\sigma}, Б_{\kappa}$ - price of basic and competing grain harvester, rub.

Factor coefficient $\mathrm{k}_{2}$ of direct costs of the competing grain harvester is calculated due to the formula

$$
k_{2}=\frac{U_{\sigma}}{U_{\kappa}}
$$

where $И_{\sigma}, И_{\kappa}$ - Direct costs of the basic and competing combine harvester, rub / unit of operating time.

Factor coefficient $\mathrm{k}_{3}$ of labor productivity of the competing grain harvester is calculated due to the formula

$$
k_{3}=\frac{3_{\kappa}}{3_{\sigma}}
$$

where $3_{\mathrm{K}}, 3_{6}$ - labor productivity of the basic and competing grain harvester, person/ unit of operating time.

Table 2. Performance characteristics of combine harvesters

\begin{tabular}{|r|l|c|c|c|}
\hline \multicolumn{1}{|c|}{ № } & \multicolumn{1}{|c|}{ Firm, model of harvester } & $\begin{array}{c}\text { Balance cost, } \\
\text { thousand rub. }\end{array}$ & $\begin{array}{c}\text { Labor costs, } \\
\text { person/ha }\end{array}$ & $\begin{array}{c}\text { Performance } \\
\text { costs, rub/ha }\end{array}$ \\
\hline \multicolumn{5}{|c|}{ Class III (5-7 kg/s) } \\
\hline 1 & LLC “HP "Rostselmash” NOVA & 4730,88 & 0,74 & 374 \\
\hline 2 & Sampo Rosenlew, SR 2085 TS- Finland & 3490 & 0,56 & 1624 \\
\hline \multicolumn{5}{|c|}{ Class IV (7-9 kg/s) } \\
\hline 1 & LLC “HP "Rostselmash”, Vector 410 & 7584 & 0,71 & 1795 \\
\hline 2 & Laverda, REV 205 ECO-Italy Class V (9-11 kg/s) & 0,58 & 2158 \\
\hline 3 & LLC “HP” Rostselmash”ACROS 550 & 16420 & 0,67 & 2126 \\
\hline \multicolumn{5}{|l|}{7875} \\
\hline 1 & LLC “HP "Rostselmach” TORUM 750 & 13299 & 0,49 & 3464 \\
\hline 2 & Claas, Lexion 760 & 33721 & 0,52 & 4834 \\
\hline 3 & New Holland, CX 8060 & 41644 & 0,47 & 2669 \\
\hline
\end{tabular}


Tables 3-5 present the results of calculations of integrated parameters of competitiveness of combine harvesters with different capacity of domestic and foreign manufacturers.

Table 3. Integrated parameters of competitiveness of class III grain harvesters

\begin{tabular}{|c|c|c|c|c|c|}
\hline \multirow[t]{2}{*}{ № } & \multirow{2}{*}{$\begin{array}{l}\text { Firm, model of grain } \\
\text { harvester }\end{array}$} & \multicolumn{3}{|c|}{ Factor coefficients } & \multirow{2}{*}{$\begin{array}{c}\text { integral } \\
\text { parameter of } \\
\text { competitiveness } \\
\mathrm{k}_{\mathrm{i}}\end{array}$} \\
\hline & & price $\mathrm{k}_{1}$ & $\begin{array}{c}\text { direct costs } \\
\mathrm{k}_{2}\end{array}$ & $\begin{array}{c}\text { labor } \\
\text { productivity } \\
\mathrm{k}_{3}\end{array}$ & \\
\hline \multicolumn{6}{|c|}{ Class III $(5-7 \mathrm{~kg} / \mathrm{s})$} \\
\hline 1 & $\begin{array}{l}\text { LLC "HP "Rostselmach" } \\
\text { NOVA }\end{array}$ & 0,737 & 4,342 & 1,321 & 2,112 \\
\hline 2 & $\begin{array}{l}\text { Sampo Rosenlew, SR } 2085 \\
\text { TS- Finland }\end{array}$ & 1,356 & 0,231 & 0,757 & 0,773 \\
\hline
\end{tabular}

Analysis of the results of calculations of integrated parameters of competitiveness of class III grain harvesters, presented in table 3, shows that the parameters of the NOVA combine harvester of LLC "HP "Rostselmash" are higher than the combine harvester of "Sampo Rosenlew" mainly due to lower operating costs $\mathrm{k}_{2}=4.3$.

Table 4. Integrated parameters of competitiveness of class IV combine harvesters

\begin{tabular}{|c|c|c|c|c|c|}
\hline \multirow[t]{2}{*}{ № } & \multirow{2}{*}{$\begin{array}{l}\text { Firm, model of grain } \\
\text { harvester }\end{array}$} & \multicolumn{3}{|c|}{ Factor coefficients } & \multirow{2}{*}{$\begin{array}{c}\text { integral parameter } \\
\text { of } \\
\text { competitiveness ki }\end{array}$} \\
\hline & & $\begin{array}{c}\text { price } \\
\mathrm{k}_{1}\end{array}$ & $\begin{array}{c}\text { direct costs } \\
\mathrm{k}_{2}\end{array}$ & $\begin{array}{c}\text { labor } \\
\text { productivity } \\
\mathrm{k}_{3}\end{array}$ & \\
\hline \multicolumn{6}{|c|}{ Class IV $(7-9 \mathrm{~kg} / \mathrm{s})$} \\
\hline 1 & $\begin{array}{l}\text { LLC "HP "Rostselmach" } \\
\text { Vector } 410\end{array}$ & 2,165 & 1,202 & 1,224 & 1,515 \\
\hline 2 & $\begin{array}{l}\text { Laverda, REV } 205 \text { ECO- } \\
\text { Italy }\end{array}$ & 0,462 & 0,832 & 0,817 & 0,696 \\
\hline 3 & $\begin{array}{l}\text { LLC "HP "Rostselmach" } \\
\text { ACROS } 550\end{array}$ & 2,085 & 1,015 & 1,155 & 1,404 \\
\hline
\end{tabular}

Analysis of the results of calculations of integrated parameters of competitiveness of grain harvesters of class IV, presented in table 4, shows that the highest coefficient of competitiveness $k_{i}$ is obtained from the combine harvester Vector 410 of the company "HP" Rostselmash" due to higher values of price coefficients $\mathrm{k}_{1}=2,165$, direct costs $\mathrm{k}_{2}=1,202$ and labor productivity $\mathrm{k}_{3}=1,224$.

The performance of the ACROS 550 combine harvester is slightly worse, and it has an integral competitiveness index $\mathrm{k}_{\mathrm{i}}=1,404$, which also corresponds to a high level of competitiveness. 
Table 5. Integrated parameters of the competitiveness of class $\mathrm{V}$ grain harvesters.

\begin{tabular}{|c|c|c|c|c|c|}
\hline \multirow[t]{2}{*}{ № } & \multirow{2}{*}{$\begin{array}{l}\text { Firm, model of grain } \\
\text { harvester }\end{array}$} & \multicolumn{3}{|c|}{ Factor coefficients } & \multirow{2}{*}{$\begin{array}{c}\text { integral } \\
\text { parameter of } \\
\text { competitiveness } \\
\mathrm{k}_{\mathrm{i}}\end{array}$} \\
\hline & & $\begin{array}{c}\text { price } \\
\mathrm{k}_{1}\end{array}$ & $\begin{array}{c}\text { direct costs } \\
\mathrm{k}_{2}\end{array}$ & $\begin{array}{c}\text { labor } \\
\text { productivity } \\
\mathrm{k}_{3}\end{array}$ & \\
\hline \multicolumn{6}{|c|}{ Class V $(9-11 \mathrm{~kg} / \mathrm{s})$} \\
\hline 1 & $\begin{array}{l}\text { LLC "HP "Rostselmach" } \\
\text { TORUM } 750\end{array}$ & 2,535 & 1,395 & 0,942 & 1,608 \\
\hline 2 & Claas, Lexion 760 & 0,394 & 0,717 & 1,061 & 0,717 \\
\hline 3 & New Holland, CX 8060 & 0,319 & 1,298 & 0,959 & 0,851 \\
\hline
\end{tabular}

Analysis of the results of calculations of integrated parameters of competitiveness of the $\mathrm{V}$ Class combine harvesters presented in table 5 shows that the combine harvester TORUM 750 LLC "HP "|Rostselmash" $\mathrm{k}_{\mathrm{i}}=1,608$, which corresponds to a high level of competitiveness in comparison with combine harvesters of this class of firms Claas (Lexion 760) and New Holland (CX 8060) mainly due to a higher factor coefficient of the price $\mathrm{k}_{1}=2,535$.

Thus, the analysis of the results of calculations of integrated parameters of competitiveness of domestic and foreign manufacturers of combine harvesters of various classes shows that the combine harvesters of LLC "HP "Rostselmash" are superior in their technical and operational indicators to similar foreign equipment mainly due to a lower price at comparable direct costs of money and labor productivity.

\section{References}

1. https://rostselmash.com/

2. http://www.sampo-rosenlew.fi/fi/etusivu.html

3. https://laverdaworld.com/.

4. https://www.claas.ru/.

5. https://agriculture.newholland.com/apac/ru-ru.

6. https://www.deere.ru/

7. Maslov G. G. Method of complex evaluation of the effectiveness of compared machines / / Tractors and agricultural machines. 2009.\#10. Pp. 31-33.

8. Trubilin, E. I. Import substitution in the mechanization of grain production (on the example of Krasnodar Territory): monograph / E. I. Trubilin, G. G. Maslov. Krasnodar: KubSAU, 2018. - 150 p.

9. Trubilin, E. I. Influence of mechanization units on the production of high-quality wheat grain: monograph / E. I. Trubilin, G. G. Maslov. - Krasnodar: KubSAU, 2019. - 232 p.

10.GOST R 53057- 2008 "Agricultural machines. METHODS OF ASSESSING COMPETITIVENESS". Moscow, Standartinform. 2009. 